\title{
EVALUASI KINERJA KONSELOR PROFESIONAL DI SMA KOMPONEN DUKUNGAN SISTEM (DISCREPANCY MODEL)
}

\author{
Maghfirotul Lathifah \\ Bimingan dan Konseling - FKIP Universitas PGRI Adibuana Surabaya \\ Maghfibk07@gmail.com
}

\begin{abstract}
ABSTRAK
Evaluasi merupakan proses mengumpulkan, menganalisis, dan mendeskripsikan informasi mengenai efektivitas pelaksanaan program bimbingan dan konseling, sehingga dapat disusun rekomendasi terkait dengan impelementasi program baik yang sudah dilaksanakan maupun belum dilaksanakan. Tujuan penelitian ini adalah mendeskripsikan kesenjangan antara realita kinerja konselor profesional dalam mengimplementasikan komponen dukungan sistem dengan standar. Penelitian ini merupakan penelitian evaluasi dengan menggunakan rancangan discrepancy model. Analisa data dalam penelitian ini adalah dengan menggunakan mixing methods. Hasil penelitian menunjukkan bahwa: Profil gabungan tiap sekolah terteliti terkait dengan kinerja konselor dalam mengimplementasikan komponen dukungan sistem di sekolah sesuai standar evaluasi kinerja konselor profesional dengan skor $73 \%$. Profil aktual yang menjadi catatan penting bagi keseluruhan sekolah terteliti ialah untuk menggagas atau memprakarsai pertumbuhan reflective practitioner dalam diri konselor.

Kata Kunci : evaluasi, kinerja konselor sekolah, komponen dukungan sistem (discrepancy model)

\section{PENDAHULUAN}

Sejarah perkembangan program bimbingan dan konseling di Indonesia berawal pada tahun 1960-an, ketika pejabat dari Departemen Pendidikan dan Kebudayaan berkunjung ke Amerika. Pada awalnya sebutan untuk

program bimbingan dan konseling ialah bimbingan dan penyuluhan. Berawal dari sebuah wacana bimbingan dan konseling di tanah air untuk menunjang misi sekolah mencapai tujuan pendidikan, maka para ahli pendidikan selanjutnya
\end{abstract}


memikirkan bagaimana caranya mengintegrasikan program $\mathrm{BK} / \mathrm{BP}$ dalam struktur lembaga pendidikan menengah (Winkel, 2006).

Bimbingan dan konseling di sekolah diprogramkan sejak diberlakukannya Kurikulum 1975, di dalam Buku III C. Kurikulum 1975 (Departemen Pendidikan Nasional, 2007) berisi ancangan layanan bimbingan dan konseling sebagai salah satu dari wilayah persekolahan mulai dari jenjang SD sampai SMA, yaitu pembelajaran yang didampingi layanan manajemen dan layanan bimbingan dan konseling. Laksmiwati (2002), menjelaskan bahwa terdapat tiga komponen pokok dalam Buku III C sebagai bagian integral yang tidak dapat dipisahkan satu sama lain. Adapun ketiga komponen tersebut adalah: (1) Program kurikulum yang baik; (2) Administrasi yang baik; (3) Pelayanan bimbingan yang terarah, disertai dengan sarana dan prasarana yang memadai. Implementasi program bimbingan dan konseling pada Kurikulum 1975 diisi oleh konselor seadanya.

Pada tahun 1984 terjadi perubahan kurikulum, namun tidak memuat hal yang berarti dalam implementasi program bimbingan dan konseling di sekolah. Kurikulum 1984 (Laksmiwati, 2002), memuat program bimbingan karier yang terdiri dari lima paket. Paket pertama berisi pemahaman diri, paket kedua berisi nilai-nilai, paket ketiga berisi pemahaman lingkungan, paket keempat berisi hambatan dan cara mengatasi hambatan, serta paket kelima berisi merencanakan masa depan. Triyono (2014) menjelaskan bahwa dengan masuknya bimbingan karier dalam program bimbingan dan konseling, program bimbingan dan konseling hampir disamakan dengan bimbingan karier. Adapun implementasi program bimbingan dan konseling dilaksanakan oleh: (1) Guru kelas sekaligus guru BP; (2) Guru bidang studi yang merangkap guru BP; (3) Guru BP yang merangkap sebagai guru bidang studi; (4) Guru BP dengan latar belakang non BP; (5) Kepala sekolah yang membimbing sekurang-kurangnya 40 siswa; (6) Guru yang memiliki minor BP; (7) Guru BP yang memiliki ijasah BP. Dari keanekaragaman latar belakang pendidikan tersebut, dikhawatirkan terjadi berbagai hambatan dalam mengimplementasikan program bimbingan dan konseling. 
Perkembangan dari Kurikulum 1984 adalah Kurikulum 1994. Departemen Pendidikan Nasional (2007) menjelaskan bahwa ketika diberlakukannya Kurikulum 1994, pelaksanaan program bimbingan dan konseling mulai mendapatkan ruang gerak dalam sistem persekolahan. Kurikulum 1994 (Laksmiwati, 2002) memuat empat bidang bimbingan dalam program bimbingan dan konseling. Keempat bidang bimbingan tersebut adalah bimbingan pribadi, sosial, belajar, dan karier.

Kurikulum 1994 disempurna kan kembali oleh Kurikulum Berbasis Kompetensi pada tahun 2002 - 2004. Pada tahun 2003, program bimbingan dan konseling mendapatkan angin segar di mana diberlakukannya UU No. 20 tahun 2003 tentang Sistem Pendidikan Nasional. Dalam UU No. 20 tahun 2003, pasal 1 ayat 6 menyebutkan bahwa keberadaan konselor dalam sistem pendidikan nasional dinyatakan sebagai salah satu kualifikasi pendidik, sejajar dengan kualifikasi guru, dosen, pamong, dan tutor. UU No. 20 tahun 2003 disempurnakan kembali dengan diberlakukannya PP 19 tahun 2005 tentang Standar Nasional pendidikan pasal 1 ayat 4 dan 5 mengenai standar kompetensi lulusan dan standar isi. Namun, terjadi kesenjangan legal di mana pada UU No, 20 tahun 2003 tidak mengatur keberadaan konselor yang menggunakan materi pengenalan diri sebagai konteks pemberian layanan. Akibatnya, ekspektasi kinerja konselor dirancukan dengan ekspektasi kinerja guru yang menggunakan materi pelajaran sebagai konteks pemberian layanan. Dampaknya adalah dipaksanya konselor secara apriori menyampaikan materi dalam konteks pemberian pelayanan (Hidayah, 2009).

Pada tahun 2006 ketika diterbitkannya Kurikulum Tingkat Satuan Pembelajaran (KTSP) hampir membawa program bimbingan dan konseling disamakan dengan pengembangan diri. Dalam Kurikulum 2006 (Departemen Pendidikan Nasional, 2007) diberlakukan Peraturan Menteri No. 22 tahun 2006 yang memuat komponen pengembangan diri dalam struktur kurikulum dan diikuti dengan panduan pengembangan diri bagi satuan pendidikan dasar dan menengah yang diterbitkan oleh Pusat Pengembangan Kurikulum dan Sarana Pendidikan Balitbang Diknas. Implementasi program bimbingan dan konseling 
dalam Kurikulum 2006 adalah pada wilayah pengembangan diri sebagai wilayah komplementer antara guru dan konselor. Pengembangan diri bukan merupakan mata pelajaran yang harus diasuh oleh guru. Akan tetapi, kegiatan pengembangan diri dapat difasilitasi atau pun dibimbing oleh konselor, guru, atau tenaga kependidikan yang dapat dilaksanakan dalam bentuk kegiatan ekstrakurikuler.

Hidayah (2009) menjelaskan bahwa akibat diberlakukannya Peraturan Menteri No. 22 tahun 2006 adalah dipaksanya konselor untuk menyampaikan materi pengembangan diri kepada peserta didik melalui konseling dan kegiatan ekstrakulikuler. Dampak dari diberlakukanya Peraturan Menteri No. 22 tahun 2006 adalah dicederainya integritas layanan bimbingan dan konseling di sekolah. Pada tahun 2007 program bimbingan dan konseling komprehensif atau bimbingan dan konseling perkembangan mulai dikembangkan di Indonesia seiring diterbitkannya buku Penataan Pendidikan Profesional Konselor dan Layanan Bimbingan dan Konseling dalam Jalur Pendidikan Formal (Departemen Pendidikan Nasional,
2007). Program bimbingan dan konseling komprehensif adalah penyempurnaan dari program sebelumnya. Orientasi program bimbingan dan konseling komprehensif ialah pada perkembangan siswa secara keseluruhan melalui empat komponen, yakni layanan dasar, perencanaan individu, layanan resposif dan dukungan sistem.

Implementasi program bimbingan dan konseling komprehensif diperkuat dengan diterbitkannya Permendiknas No. 27 tahun 2008 tentang Standar Kualifikasi Akademik dan Kompetensi Konselor pasal 1 dan 2. Namun, kondisi implementasi program bimbingan dan konseling di lapangan berbeda dengan isi dari Permendiknas No. 27 tahun 2008 yakni masih banyak konselor dengan kualifikasi non BK serta program bimbingan dan konseling komprehensif belum diimplementasikan oleh para konselor di sekolah.

Tahun 2013 pemerintah memberlakukan Kurikulum 2013 sebagai penyempurnaan Kurikulum Tingkat Satuan Pembelajaran. Kurikulum 2013 diperkuat dengan diterbitkannya Permendikbud 81A 
tahun 2013 disempurnakan kembali dengan Permendikbud No 111 Tahun 2014 tentang Bimbingan dan Konseling Pada Pendidikan Dasar dan Menengah. Namun, karena Kurikulum 2013 masih tergolong baru maka implementasi dari kurikulum tersebut belum merata di daerah-daerah.

Perkembangan program bimbingan dan konseling di sekolah mulai dari tahun 1975 sampai 2012 dapat disimpulkan bahwa program bimbingan dan konseling merupakan bagian integral dari sistem pendidikan. Namun, pada prakteknya muncul persoalan-persoalan seperti belum diimplementasikannya program bimbingan dan konseling komprehensif di sekolah, banyaknya konselor berlatar belakang non $\mathrm{BK}$, penyamarataan ekspektasi kinerja konselor dengan ekspektasi kinerja guru yang berdampak pada dipaksanya konselor secara apriori menyampaikan materi dalam konteks pemberian pelayanan. Persoalanpersoalan tersebut menunjukkan adanya kesenjangan sehubungan dengan kinerja konselor dalam mengimplementasikan program bimbingan dan konseling di sekolah.

Hambatan sekaligus masalah yang terjadi mengindikasikan adanya kesenjangan ekspektasi kinerja konselor profesional dalam mengimplementasikan program. Hambatan tersebut menjadi salah satu penyebab minimnya akuntabilitas konselor dalam mengimplementasikan program. Akuntabilitas program terwujud dalam kejelasan program, proses implementasi, dan hasil yang dicapai berupa informasi yang menjelaskan apa dan mengapa suatu proses dan hasil terjadi atau tidak, terkait dengan keberhasilan atau kegagalan peserta didik dalam mencapai kompetensi (Santoso, 2009). Akibat dari kesenjangan ekspektasi kinerja konselor profesional dalam mengimplementasikan program adalah konselor takut untuk mendapatkan hasil evaluasi yang negatif. Hal tersebut dikarenakan profesionalitas kinerja konselor dalam mengimplementasikan program saat ini dinilai hanya dari sertifikat bukan kegiatan real yang dilakukan. Dampaknya adalah pertama, program yang telah dibuat oleh konselor dari tahun ke tahun adalah program yang sama, yang berbeda hanyalah tahun pembuatan dan nama kepala sekolah. Kedua, program yang berjalan tidak mempunyai tujuan dan sasaran yang tepat, pada akhirnya terjadi 
ketidaksesuaian antara program mendalam konseli; (2) menguasai dengan implementasinya.

Konselor adalah tenaga pendidik berkualifikasi strata satu (S-1) program bimbingan dan konseling dan merupakan motor penggerak utama dalam mengimplementasi program bimbingan dan konseling di sekolah. Tugas konselor berada pada area pelayanan profesional yang bertujuan untuk mengembangkan potensi serta memandirikan peserta didik dalam mengambil keputusan berkenaan dengan pilihannya dalam hal pribadi, sosial, belajar, maupun karier. Dalam mengimplementasikan program bimbingan dan konseling di sekolah konselor senantiasa digerakkan oleh motif altruistik, empati, menghormati keragaman, serta mengutamakan kepentingan konseli dengan selalu mencermati dampak pelayanan yang telah diberikan baik jangka pendek maupun jangka panjang.

Sosok utuh kompetensi konselor profesional mancakup kompetensi akademik dan kompetensi profesional. Kompetensi akademik merupakan landasan ilmiah dari kiat implementasi program bimbingan dan konseling dan merupakan landasan pengembangan kompetensi profesional, yang meliputi: (1) memahami secara landasan dan kerangka teoritik bimbingan dan konseling; (3) menyelenggarakan program bimbingan dan konseling yang memandirikan; (4) mengembangkan pribadi dan profesionalitas konselor secara berkelanjutan (Permendiknas No 27 tahun 2008). Unjuk kerja konselor dipengaruhi oleh keempat kompetensi tersebut yang didasari oleh sikap, nilai, dan karakteristik pribadi yang mendukung.

Salah satu hal penting berkaitan dengan profesinalitas kinerja konselor adalah supervisi kinerja konselor. Taufiq (2004) mengungkapkan bahwa pelaksanaan supervisi kinerja konselor selama ini belum diarahkan pada upaya peningkatan mutu profesionalisme konselor sekolah secara berkelanjutan. Praktik supervisi kinerja konselor yang terjadi di lapangan didasarkan atas konsep pengawasan guru mata pelajaran, sehingga bukan saja tidak efektif melainkan memberikan dampak yang destruktif terhadap perkembangan profesionalitas konselor sekolah. Mc. Leod (2003), menjelaskan bahwa supervisi merupakan salah satu elemen penting dalam perkembangan konselor sepanjang kariernya dan 
bukan hanya terletak pada pendidikan semata. Namun, realita di lapangan menunjukkan bahwa kegiatan supervisi yang dilakukan cenderung mensupervisi program bimbingan dan konseling, sedangkan kinerja konselor profesional terabaikan.

Penelitian ini dilakukan dalam upaya memberikan perhatian terhadap profesionalitas kinerja konselor dalam mengimplementasikan program bimbingan dan konseling di sekolah. Evaluasi merupakan langkah awal dalam supervisi, dan pada umumnya diartikan sebagai proses atau usaha untuk menghasilkan penilaian (Fitzpatrick, 2004). Implementasi program bimbingan dan konseling di sekolah erat kaitannya dengan kinerja konselor. Dengan demikian, tanpa adanya evaluasi tidak memungkinkan terjadi suatu perbaikan karena tidak terjadi umpan balik. Fokus evaluasi dalam penelitian ini adalah kinerja konselor profesional dalam mengimplementasikan komponen dukungan sistem di sekolah, dengan menggunakan discrepancy model yang dikembangkan oleh Malcom Provus (Fitzpatrick, 2004). Evaluasi discrepancy model berusaha untuk melihat kesenjangan antara kinerja konselor profesional dalam mengimplementasikan

program dengan realita di lapangan.

\section{METODE}

Penelitian ini menggunakan standar evaluasi kinerja konselor profesional diadaptasi dari buku Guidelines for Performance Based Profesional School Counselor Evaluation (Missiouri Department of Elementary and Secondary Education, 2000). Tujuan penelitian ini adalah mendeskripsikan kesenjangan antara realita kinerja konselor profesional dalam mengimplementasikan komponen dukungan sistem dengan standar. Secara rinci tujuan penelitian ini adalah sebagai berikut. (1) Mendeskripsikan kinerja konselor dalam mengimplementasikan komponen dukungan sistem di sekolah; (2) Mendeskripsikan ketercapaian tujuan implementasi komponen dukungan sistem di sekolah untuk diambil keputusan apakah kinerja konselor masih jauh, mendekati, ataukah sesuai dengan standar kinerja konselor profesional; (3) Menemukan kesenjangan antara standar dan realita kinerja konselor dalam mengimplementasikan komponen dukungan sistem di sekolah. 
Penelitian ini dilaksanakan pada bulan Desember 2014 sampai Februari 2015. Secara umum populasi penelitian ini adalah sepuluh SMA di Kabupaten Gresik, sedangkan target populasinya adalah guru bimbingan dan konseling atau konselor yang berada pada sepuluh sekolah. Sampel yang digunakan dalam penelitian ini diambil secara cluster random sampling dari anggota populasi. Prosedur penelitian evaluasi kinerja konselor sekolah profesional, digambarkan sebagai berikut.

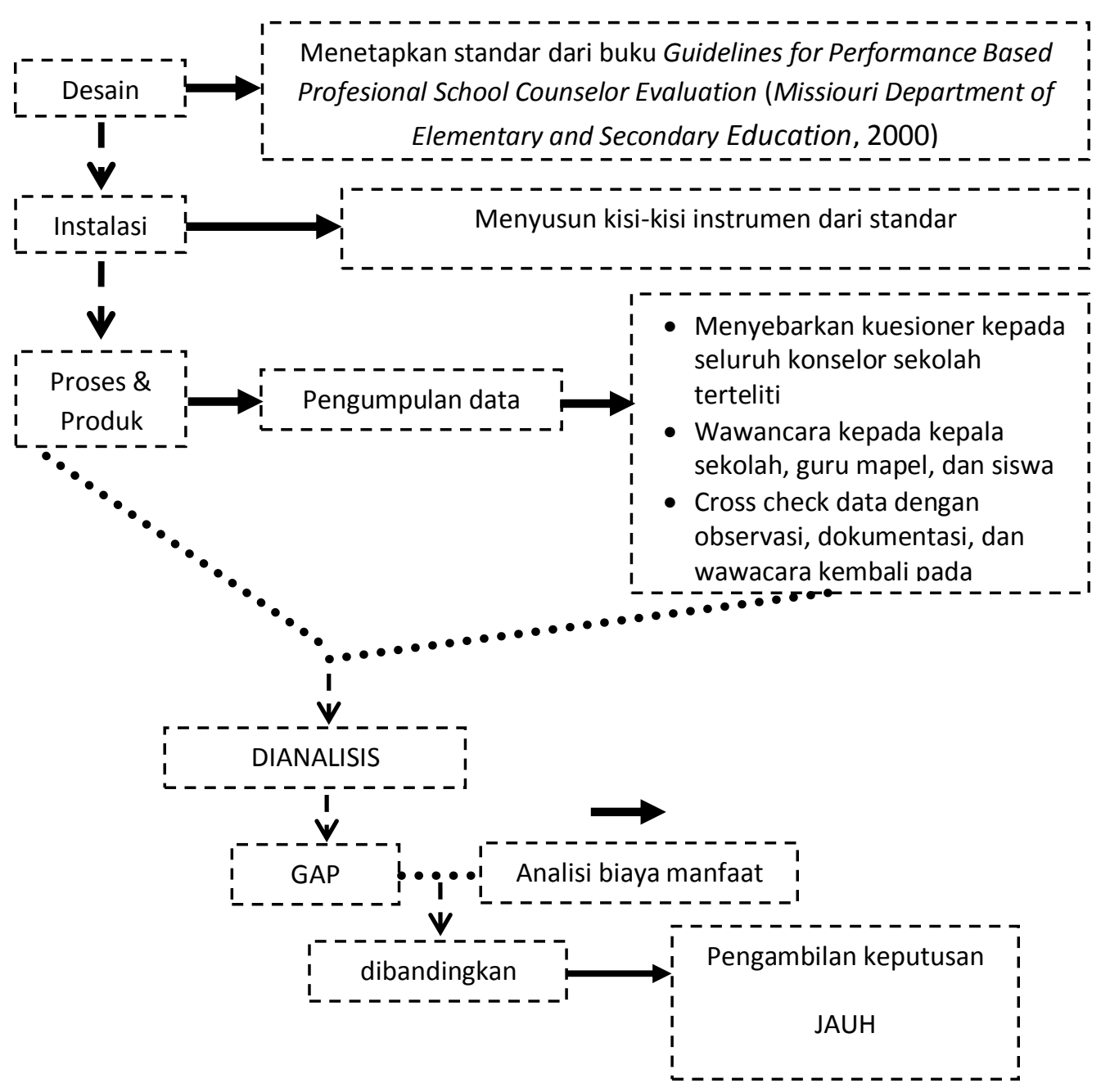

Gambar 1 Prosedur Penelitian Evaluasi Kinerja Konselor Profesional 
Analisa data dalam penelitian

ini dilakukan secara deskriptif kuantitatif dan deskriptif kualitatif. Perhitungan data angka dengan cara mengolah angka-angka yang telah ditetapkan sebagai pencerminan pelaksanaan komponen dukungan sistem di sekolah terkait dengan kinerja konselor. Terdapat tiga kriteria interpretasi untuk kecenderungan hasil jawaban responden. (1) $67 \%$ - 100\% Kinerja konselor profesional di SMA sesuai dengan standar kinerja konselor profesional; (2) 34\% - 66\% Kinerja konselor profesional di SMA mendekati kinerja konselor profesional; (3) $0 \%$ - 33\% Kinerja konselor profesional di SMA jauh dari standar kinerja konselor profesional.

Perhitungan data yang bersifat non angka yakni dengan mendeskripsikan hasil wawancara kepada kepala sekolah, konselor, guru mata pelajaran dan siswa. Hasil data angka maupun non angka akan dielaborasi untuk mendapatkan hasil evaluasi kinerja konselor di sekolah dalam

mengimplementasikan komponen dukungan sistem di sekolah, apakah jauh, mendekati ataupun sesuai dengan standar evaluasi kinerja konselor professional diadaptasi dari buku Guidelines for Performance-Based Professional School Counselor (Missiouri Department of Elementary and Secondary Education, 2000).

1. Analisis Komparatif Termodifikasi Analisis komparatif termodifikasi dimaksudkan sebagai proses untuk membandingkan hasil yang diperoleh dari tiap sekolah (SMA A sampai SMA J) dan tiap wilayah.

2. Analisis Komparatif Konstan

Analisis komparatif konstan dimaksudkan untuk menganalisis tiap sekolah terteliti dan tiap wilayah untuk dibandingkan dengan criterion matrix.

\section{HASIL DAN PEMBAHASAN}

Evaluasi kinerja konselor profesional di SMA komponen dukungan sistem (discrepancy model) sesuai standar kinerja konselor profesional dengan skor sebesar $73 \%$. Kedelapan fokus diantaranya yang 
paling dekat ialah fokus $8,9,12$, menyadari keterbatasan dan sebaliknya fokus $10,11,13,14,15$ kemampuan yang dimiliki termasuk jauh dari standar. Sebagian besar konselor pada keseluruhan sekolah terteliti belum memegang tanggungjawab profesional. Temuan di lapangan menunjukkan lemahnya komitmen terhadap profesi bimbingan dan konseling. Temuan faktual tersebut kurang sesuai dengan harapan standar kinerja konselor profesional diadaptasi dari buku Guidelines for Performance Based Profesional School Counselor Evaluation (Missiouri Department of Elementary and Secondary Education, 2000).

Temuan di lapangan juga mengindikasikan lemahnya reflective practitioner yang dimiliki oleh konselor pada seluruh sekolah terteliti dan rendahnya praktik supervisi program bimbingan dan konseling di sekolah. Konselor dalam praktiknya akan menghadapi situasi unik dan kompleks yang mungkin hanya dapat dipecahkan dengan pendekatan. Reflective practitioner menurut Schon (1983) merupakan praktik atau kerja nyata konselor, dimana konselor

kelebihan dan kekurangan, mampu mengimplementasikan program bimbingan dan konseling sesuai dengan tujuan, mampu mengontrol tingkat kejenuhan atau burnout, sadar terhadap hal-hal pribadi yang dapat menghambat kinerjanya sebagai konselor sekolah, mampu meluangkan waktu untuk mengevaluasi dan memperbaiki kinerjanya, serta berkomitmen untuk mengembangkan profesionalitasnya. Reflective practitioner akan terwujud apabila konselor mampu melaksanakan tugas sesuai dengan profesi, merekam serta merefleksikan hasil, dan dampak dari kinerjanya.

Hawkins \& Sohet (2006) menjelaskan bahwa supervision is a quintenssential interpersonal interaction with the general goal that one person, the supervisor, meets with another, the supervisee in an effort to make the latter more effetctive in helping people. Pedersen (2007) menjelaskan bahwa supervisor mempunyai tiga peran, yakni sebagai penasehat, guru, dan konsultan. 
Supervisor sebagai penasehat akan berpartisipasi dengan konselor dalam mengeksplorasi kemampuan konselor, menyadari nilai-nilai dan kemungkinan bias, serta menghadapi berbagai emosi yang akan terjadi. Supervisor sebagai guru akan memberikan pengetahuan baru, sebagai model atau menunjukkan kepada konselor dengan contoh, mengamati serta memberikan umpan balik kepada konselor terkait dengan kinerjanya. Sebagai konsultan, supervisor akan mengadakan pertemuan dengan konselor yang menekankan pada komitmen profesional dan perbaikan.

Dengan demikian, sangatlah penting untuk menindaklanjuti atau memfollow up kinerja konselor dalam mengimplementasikan komponen dukungan sistem melalui supervisi, sehingga dapat menumbuhkan reflective practitioner dalam diri konselor serta dapat meningkatkan kualitas atau mutu program bimbingan dan konseling di sekolah. Supervisor yang dibutuhkan ialah mereka yang berlatar belakang bimbingan dan konseling, pernah mengampu mata kuliah praktikum bimbingan dan konseling, dan pernah mengikuti pelatihan atau training, salah satunya seperti sertifikasi tes.

\section{SIMPULAN DAN SARAN}

Sesuai dengan tujuan penelitian dapat disimpulkan secara umum, temuan gabungan tiap sekolah terteliti sesuai standar evaluasi kinerja konselor profesional. Kedelapan fokus di antaranya yang paling dekat ialah fokus 8 konselor sekolah profesional memberikan program bimbingan komprehensif seimbang komponennya bersama dengan staf sekolah lainnya; konselor sekolah profesional memberikan dukungan terhadap program sekolah lainnya; konselor sekolah profesional memperlihatkan hubungan interpersonal yang positif dengan orangtua dan tokoh masyatakat sekitar sekolah, sebaliknya fokus yang lain masih jauh. Lebih lanjut profil aktual kinerja konselor pada tiap-tiap sekolah terteliti bervariasi.

Berdasarkan temuan penelitian yang telah dipaparkan, maka diajukan sejumlah saran yaitu: (1) Bagi 
konselor pada tiap-tiap sekolah terteliti diharapkan mau belajar untuk terus mengembangkan dan memperbaharui kemampuan dan keterampilan yang dimiliki, sehingga dapat meningkatkan mutu atau kualitas program bimbingan dan konseling di sekolah; (2) ABKIN Daerah sebagai wadah organisasi yang menaungi program bimbingan dan konseling diharapkan bisa memonitoring mutu atau kualitas kinerja konselor dalam mengimplementasikan program bimbingan dan konseling di sekolah sehingga bermuara pada pertumbuhan reflective practitioner dalam diri konselor; (3) Hasil penelitian ini merupakan hasil rintisan, maka diharapkan ABKIN Daerah dapat melakukan penelitian serupa dalam skala yang lebih besar guna memperbaiki kualitas kinerja konselor di masa depan.

\section{DAFTAR RUJUKAN}

A Model Comprehensive, Development Guidance and Counse-ling Program for Texas Public Schools. 2004. A Guide for Program Develop-ment Pre - K
Grade,

(Online),(www.tea.state.tx.us/c ounseling-guidebook.html) , diakses 4 Maret 2013.

Departemen Pendidikan Nasional. 2007. Penataan Pendidikan Profesional Konselor dan Layanan Bimbingan dan Konseling Dalam Jalur Pendidikan Formal. Bandung : Penerbit UPI.

Fitzpatrick L Jody, Sanders R James, Worthen R Blaine. 2004. Program Evaluation Alternative Approaches and Guidlines (3thed). USA: Pearson Education,Inc.

Hawkins. P \& Sohet. R. 2006. Supervision In The Helping Profession. England: Open University Press.

Hidayah, Nur. 2009. Process Audit dalam Penyelenggaraan Pendidikan Akademik Jenjang S-1 Bimbingan dan Konseling. Disertasi tidak dipublikasikan. Malang: PPS Universitas Negeri Malang.

Keputusan Bersama Mendikbud dan BAKN No. 0433/P/1993 No. 25 Tahun 1993 tentang Juklak Jabatan Fungsional Guru dan Angka Kreditnya. (Online), (konselingindonesia.com), diakses 16 Mei 2013. 
Keputusan Menteri Negara

Pendayagunaan Aparatur

Negara No. 84 Tahun 1993

tentang Jabatan Fungsional

Guru dan Angka Kreditnya.

(Online),

(gurupembaharu.com), diakses 16 Mei 2013.

Mcleod John. 2006. Pengantar Konseling Teori dan Studi Kasus. Jakarta: Kencana.

Missiouri Departement of Elementary and Secondary Education. 2000. Guidelines for Performance-Based Professional School Counselor Evaluation (Online), diakses 4 Maret 2013.

Modul Pelatihan Implementasi Kurikulum 2013 Untuk Guru BK/Konselor. Implementasi Pelayanan Bimbingan dan Konseling. 2013. Kementrian Pendi-dikan dan Kebudayaan.

Modul Pelatihan Implementasi Kurikulum 2013 Untuk Guru BK/Konselor. Evaluasi, Pelaporan dan Peminatan dan Tindak Lanjut Pelayanan Peserta Didik. 2013. Kementrian Pendidikan dan Kebudayaan.

Pedersen Laura. 2007. School Supervisor's Manual For Internship: School Counseling Program: SCED 516. Portland: Lewis \& Clark College.
Pedoman Penulisan Karya Ilmiah:

Skripsi, Tesis, Disertasi, Artikel, Makalah, Tugas Akhir, Laporan Penelitian Edisi Kelima. 2010. Malang: Universitas Negeri Malang.

Peraturan Menteri Pendidikan dan Kebudayaan 81A Tahun 2013 tentang Impelementasi Kurikulum, (Online), (akhmadsudrajat.wordpress.co m), diakses 5 April 2014.

Peraturan Menteri Pendidikan Nasional No. 22 Tahun 2006 tentang Standar Isi untuk Satuan Pendidikan Dasar dan Menengah. Jakarta:

Departemen Pendidikan

Nasional.

Peraturan Menteri Pendidikan Nasional No. 27 Tahun 2008 tentang Standar Kualifikasi Akademik dan Kompetensi Konselor. Jakarta: Departemen Pendidikan Nasional.

Peraturan Menteri Pendidikan Nasional No. 39 Tahun 2009 tentang Pemenuhan Beban Kerja Guru dan Pengawas Satuan Pendidikan. Jakarta: Departemen Pendidikan Nasional.

Peraturan Pemerintah No. 29 Tahun 1990 tentang Pendidikan Menengah.

(www.hukumonline.com), diakses 16 Mei 2013. 
Provus M Malcom. 1969. The Discrepancy Evaluation Model An Approach to Local Program Improvement and Development (Online),

(files.eric.ed.gov/fulltext/ED03 0957.pdf), diakses 1 September 2014.

Santoso Budi Djoko. 2009. Dasardasar Bimbingan dan Konseling. Malang: Universitas Negeri Malang.

Schön Donald. 1983. The Reflective

Practitioner, How Professional Think In Actiion. USA: Basic Books, Inc.

Taufiq Agus. 2004. Model Supervisi Kinerja Konselor Untuk Meningkatkan Kompetensi Profesional Konselor Di Sekolah Menengah Atas. Malang: Jurusan Studi Bimbingan dan Konseling FIP Universitas Negeri Malang dan ABKIN.

Triyono. 2014. Paradigma Bimbingan dan Konseling dalam Sistem Pendidikan Di Indonesia, (karyailmiah.fip.um.ac.id/paradi gma-bimbingan-dan-konselingdalan-sistem-pendidikan-diindonesia.html) diakses $14 \mathrm{Mei}$ 2014.

Triyono. 2014. Bimbingan dan Konseling dari Konvensional Menuju Konstruktivistik. Makalah disajikan dalam
Seminar Nasional Bimbingan dan Konseling Arah Baru Pendidikan dan Profesionalisasi Guru Bimbingan dan Konseling atau Konselor, Malang, 15 Juni 2014.

Winkel. W.S, Hastuti Sri M.M. 2006. Bimbingan dan Konseling Di Institusi Pendidikan. Yogyakarta: Media Abadi. 
